\title{
Regulation of Xanthine Dehydrogenase and Xanthine Oxidase Activity and Gene Expression in Cultured Rat Pulmonary Endothelial Cells
}

\author{
Gregory P. Dupont, ${ }^{\star}$ Thomas P. Huecksteadt, ${ }^{*}$ Bruce C. Marshall, ${ }^{\star}$ Una S. Ryan, ${ }^{\ddagger}$ John R. Michael, ${ }^{\star}$ and John R. Hoidal \\ *Department of Medicine, University of Utah School of Medicine and the Veterans Administration Medical Center, \\ Salt Lake City, Utah 84132; and ${ }^{\ddagger}$ Monsanto Company and Washington University, St. Louis, Missouri 63167
}

\begin{abstract}
The central importance of xanthine dehydrogenase (XDH) and xanthine oxidase (XO) in the pathobiochemistry of a number of clinical disorders underscores the need for a comprehensive understanding of the regulation of their expression. This study was undertaken to examine the effects of cytokines on XDH/ XO activity and gene expression in pulmonary endothelial cells. The results indicate that IFN- $\gamma$ is a potent inducer of $\mathrm{XDH} / \mathrm{XO}$ activity in rat lung endothelial cells derived from both the microvasculature (LMVC) and the pulmonary artery. In contrast, interferon- $\alpha / \beta$, tumor necrosis factor- $\alpha$, interleukin-1 or -6 , lipopolysaccharide and phorbol myristate acetate have no demonstrable effect. The increase in XDH/XO activity requires new protein synthesis. By Northern analysis, IFN- $\gamma$ markedly increases the level of the 5.0-kb XDH/XO mRNA in LMVC. The increase is due, in part, to increased transcription rate of the XDH/XO gene. Transcriptional activation does not require new protein synthesis. The physiologic relevance of these observations was evaluated by administering IFN- $\gamma$ to rats. Intraperitoneal administration leads to an increased $\mathrm{XDH} / \mathrm{XO}$ activity and XDH/XO mRNA level in rat lungs. In sum, IFN- $\gamma$ is a potent and biologically relevant inducer of $\mathrm{XDH} / \mathrm{XO}$ expression; the major site of upregulation occurs at the transcriptional level. (J. Clin. Invest. 1992. 89:197-202.) Key words: interferon gamma • lung microvascular • pulmonary artery
\end{abstract}

\section{Introduction}

Xanthine dehydrogenase (XDH) is a molybdenum iron-sulfur flavin hydroxylase widely distributed among animal species and tissues. The enzyme oxidizes a variety of purines, pyrimidines, pteridines, and other heterocyclic nitrogenous compounds. It serves as a rate-limiting enzyme in nucleic acid degradation through which all purines are channeled for terminal oxidation. The mammalian form of the enzyme has a built-in

Address correspondence to John Hoidal, M.D., Division of Respiratory, Critical Care and Occupational Medicine, University of Utah Health Sciences Center, 50 N. Medical Drive, Salt Lake City, UT 84132. 1991.

Received for publication 22 May 1991 and in revised form 26 July

1. Abbreviations used in this paper: LMVC, rat lung microvascular cells; PAEC, pulmonary artery endothelial cells; $\mathrm{XDH}$, xanthine dehydrogenase; $\mathrm{XO}$, xanthine oxidase.

J. Clin. Invest.

(C) The American Society for Clinical Investigation, Inc. 0021-9738/92/01/0197/06 \$2.00

Volume 89, January 1992, 197-202 switch mechanism that converts the NAD-dependent dehydrogenase form (XDH, EC 1.1.1.204) to the $\mathrm{O}_{2}$-dependent oxidase form (XO, EC 1.1.3.22). This conversion may occur through reversible sulfhydryl oxidation or irreversible proteolytic modification.

A notable property of the oxidase form, $\mathrm{XO}$, is that it generates the reactive $\mathrm{O}_{2}$ species superoxide anion $\left(\mathrm{O}_{2}^{-}\right)$and hydrogen peroxide $\left(\mathrm{H}_{2} \mathrm{O}_{2}\right)$. During the past decade, a substantial amount of information has accumulated that identifies endothelial cells as important sources of XO and that identifies XOmediated endothelial injury as a major cause of damage occurring in ischemic tissue during reperfusion $(1,2)$. Reperfusion injury likely hinges on two critical events that occur during ischemia: degradation of cellular stores of ATP to the purines hypoxanthine and xanthine, and conversion of $\mathrm{XDH}$ to $\mathrm{XO}$. During reperfusion, the sudden availability of $\mathrm{O}_{2}$ as a cofactor allows $\mathrm{XO}$ to convert the accumulated purine substrate to uric acid with byproduct formation of $\mathrm{O}_{2}^{-}$and $\mathrm{H}_{2} \mathrm{O}_{2}$. Reperfusion injury mediated by XO-derived reactive $\mathrm{O}_{2}$ species has been reported in most organs studied to date.

In addition to the role of $\mathrm{XO}$ in ischemia-reperfusion injury, recent studies indicate that disturbances in energy metabolism, without tissue ischemia, can lead to breakdown of ATP and promote XO-mediated injury. XO-derived reactive $\mathrm{O}_{2}$ species have been proposed as important mediators in the pathogenesis of infant respiratory distress (3), the adult respiratory distress syndrome (4), burn injury (5), hematoporphyrin derivative-mediated cutaneous photosensitization (6), neutrophil elastase-mediated injury to isolated perfused lungs and cultured endothelium (7), and recently, lung injury caused by the influenza virus (8).

The knowledge that XO plays a central role in the pathobiochemistry of many clinical disorders has accentuated the need for a comprehensive understanding of the regulation of its expression. Because inflammation is a dominant feature of many of these disorders, we explored the ability of inflammatory mediators to regulate $\mathrm{XDH} / \mathrm{XO}$. We focused primarily on the effect of cytokines that cause endothelial cell activation and we investigated their effect on $\mathrm{XDH} / \mathrm{XO}$ activity in rat lung microvascular cells (LMVC) and pulmonary artery endothelial cells (PAEC). We also sought to define the basis for the increased activity by examining $\mathrm{XDH} / \mathrm{XO}$ mRNA transcript levels.

\section{Methods}

Materials. Reagents were obtained as follows: tissue culture media from Gibco (Grand Island, NY); FCS from HyClone Laboratories (Logan, UT); tissue culture plasticware from Costar (Cambridge, MA); $\left[\alpha-{ }^{32} \mathrm{P}\right] \mathrm{dCTP}$ and UTP from Amersham Corp. (Arlington Heights, IL); Duralose nitrocellulose membranes from Stratagene Inc. (La Jolla, CA); Kodak XAR film from Eastman Kodak Co. (Rochester, NY); rat IFN- $\gamma$ from Amgen Biologicals (Thousand Oaks, CA); rat IFN- $\alpha / \beta$ 
from Lee Biomolecular Research Laboratory Inc. (San Diego, CA); human recombinant tumor necrosis factor- $\alpha$ (TNF- $\alpha$ ) from Genzyme Corp. (Cambridge, MA); human IL-1 and IL-6 from R \& D Systems, Inc. (Minneapolis, MN); collagenase type 2 from Worthington Biochemical Corp. (Freehold, NJ). All other reagents unless specifically stated were from Sigma Chemical Co. (St. Louis, MO).

Sources of cells and cell culture. Rat LMVC were initially isolated with microcarrier beads as previously described (9). The isolated cells have a cobblestone morphology by both light and electron microscopy and have been identified as endothelial cells by the presence of Factor VIII antigen (10) and by the uptake of acetylated low density lipoproteins (11). The cells were maintained in monolayer culture at $37^{\circ} \mathrm{C}$ and $5 \% \mathrm{CO}_{2}$ using Ryan's red medium (M199, 6.7\% bovine calf serum, $3.3 \% \mathrm{FBS}$, thymidine, L-glutamine, penicillin, streptomycin, and gentamicin). The cells were passaged without enzymes and plated onto 100-mm dishes for study. Upon reaching confluence, the cells were replenished with fresh media in the presence or absence of inflammatory mediators. At selected times between 2 and $48 \mathrm{~h}$ after exposure to mediators, the cells were washed with PBS, harvested and processed for measurement of $\mathrm{XDH} / \mathrm{XO}$ activity or preparation of mRNA. Rat PAEC were harvested from Sprague-Dawley rats by previously described methods (9). Briefly, under sterile conditions the main pulmonary artery was removed, the lumen washed three times in HBSS, filled with HBSS containing $1 \mathrm{mg} / \mathrm{ml}$ of collagenase type 2 , closed by placing sterile removable clips at the ends, and incubated at $37^{\circ} \mathrm{C}$ for $30 \mathrm{~min}$. After incubation, the endothelium was scraped with a sterile forceps. The PAEC were then recovered by centrifugation and plated in Ryan's red medium. Studies were performed on cells following their first or second passage.

Quantification of $X D H / X O$ activity. The spectrofluorometric assay recently described by Beckman et al. was used with slight modifications (12). Briefly, confluent monolayers washed twice with PBS were mechanically detached and sonicated in extraction buffer containing 0.1 mM EDTA, $1 \mathrm{mM}$ PMSF, and $10 \mathrm{mM}$ dithiothreitol in $50 \mathrm{mM}$ phosphate buffer, $\mathrm{pH}$ 7.4. The cell lysates were centrifuged at $25,000 \mathrm{~g}$ for 30 $\min \left(4^{\circ} \mathrm{C}\right)$. The supernatants were chromatographed through prepacked Sephadex G-25 columns (Pharmacia, Inc., Piscataway, NJ) to remove endogenous purines that may compete for $\mathrm{XDH} / \mathrm{XO}$. The sample was diluted to $2 \mathrm{ml}$ in $50 \mathrm{mM}$ phosphate buffer containing $0.1 \mathrm{mM}$ EDTA (pH 7.4). Fluorescence was monitored at $390 \mathrm{~nm}$ with excitation wavelength set at $345 \mathrm{~nm}$. After achieving a stable baseline, $20 \mu \mathrm{l}$ of $1 \mathrm{mM}$ pterin was added and the reaction was observed for 2-20 min to assay XO activity. Subsequently, $20 \mu \mathrm{l}$ of $1 \mathrm{mM}$ methylene blue was added as an electron acceptor to assay total $\mathrm{XDH} / \mathrm{XO}$ activity. Allopurinol $(20 \mu \mathrm{l}$ of $2 \mathrm{mM})$ was then added to confirm specificity of the reaction. $0.01 \mathrm{mM}$ isoxanthopterin was added as an internal standard after its exact concentration was determined spectrally $\left(E_{336}=13.0\right.$ $\mathrm{mM}^{-1} \mathrm{~cm}^{-1}$ ). Activity was expressed as nanomoles of isoxanthopterin formed/min per $\mathrm{mg}$ protein. Protein concentrations were determined by dye-binding assay (Bio-Rad Laboratories, Cambridge, MA). Sample processing had minimal effect on XDH/XO activity. A mean of $87 \%$ of exogeneous $\mathrm{XO}$ added to cell suspensions was detected by this assay after processing as described above.

Evaluation of XDH/XO mRNA transcript level. To obtain XDH/
XO cDNA probes, first-strand CDNA was synthesized from rat liver mRNA by using avian myeloblastosis virus reverse transcriptase and random hexamer primers. The product was then used as a template for PCR amplification using oligonucleotide primers specific to regions of the rat liver XDH/XO cDNA (13). By direct sequencing using the dideoxynucleotide chain termination method (14), the amplification products were verified to be identical to bases 364 to 1338 and 2206 to 3453 of the XDH/XO cDNA.

For Northern analysis, total RNA was prepared by guanidinium isothiocyanate-phenol-chloroform extraction (15). The mRNA was isolated using oligo (dT) magnespheres, separated on the basis of size on a $2.2 \mathrm{M}$ formaldehyde/1\% agarose gel, transferred to a Duralose membrane by capillary action and linked to the membrane by baking at $80^{\circ} \mathrm{C}$ for $2 \mathrm{~h}$. The membranes were prehybridized overnight at $42^{\circ} \mathrm{C}$ in $5 \times \mathrm{SSC}$ (standard sodium citrate), $5 \times$ Denhardt's solution, $0.1 \mathrm{mg} /$ $\mathrm{ml}$ of salmon sperm DNA, $1 \%$ SDS, and $50 \%$ formamide. The XDH/ XO cDNA probe or the control CHO-B cDNA probe (16) was ${ }^{32} \mathrm{P}-\mathrm{la}-$ beled by the random primer method and hybridized at $42^{\circ} \mathrm{C}$ overnight in $5 \times \mathrm{SCC}, 2 \times$ Denhardt's solution, $0.1 \mathrm{mg} / \mathrm{ml}$ salmon sperm DNA, $1 \%$ SDS, and $50 \%$ formamide. The membranes were washed in $0.1 \times$ SSC, $0.2 \%$ SDS three times at $51^{\circ} \mathrm{C}$. Autoradiography was performed, and bands were quantitated by laser densitometry.

Evaluation of $X D H / X O$ gene transcription rate. The relative transcription rate of the $\mathrm{XDH} / \mathrm{XO}$ gene was evaluated using nuclear transcription run-on analysis $(17,18)$. Approximately $1 \times 10^{8}$ nuclei were incubated with $200 \mu \mathrm{Ci}$ of $\left[\alpha{ }^{32} \mathrm{P}\right] \mathrm{UTP}(800 \mathrm{Ci} / \mathrm{mmol})$ at $30^{\circ} \mathrm{C}$ for 30 min. The ${ }^{32} \mathrm{P}$-labeled RNA was isolated and resuspended to give equal number of counts per minute. Nitrocellulose filters were spotted with $10 \mu \mathrm{g}$ of denatured DNA using a slot blot apparatus (Schleicher \& Schuell, Keene, NH). Hybridization was performed at $65^{\circ} \mathrm{C}$ for $36 \mathrm{~h}$ followed by high stringency wash at $60^{\circ} \mathrm{C}$ with $0.1 \times \mathrm{SSC}$ and $0.1 \%$ SDS. Autoradiography was performed and bands were quantitated by laser densitometry.

Statistical analysis. Data are presented as mean \pm SEM, unless stated otherwise. Statistical significance of differences was assessed by analysis of variance (19), with significance assumed when $P<0.05$.

\section{Results}

Effect of inflammatory mediators on XDH/XO activity in endothelial cells. We initially studied the effect of inflammatory mediators on $\mathrm{XDH} / \mathrm{XO}$ activity in pulmonary endothelial cells (Fig. 1). IFN- $\gamma$ was a potent inducer of $\mathrm{XDH} / \mathrm{XO}$ activity. After 24-h exposure to $1000 \mathrm{U} / \mathrm{ml} \mathrm{IFN}-\gamma$, the XDH/XO activity in LMVC increased fivefold (Fig. $1 A$ ). XO was $\sim 20 \%$ of the total $\mathrm{XDH} / \mathrm{XO}$ activity, which was the same percentage as in unstimulated control cells. Increased XDH/XO activity was first detectable at $6 \mathrm{~h}$ of IFN- $\gamma$ exposure, and maximal induction of approximately 10 -fold was observed after $48 \mathrm{~h}$ of exposure (Fig. $2 A$ ). The effect of IFN- $\gamma$ was present over a wide concentration range (Fig. $2 \mathrm{~B}$ ). Exposure to $1 \mathrm{U} / \mathrm{ml} \mathrm{IFN}-\gamma$ for $24 \mathrm{~h}$ increased XDH/XO activity $\sim 50 \%$, while $100 \mathrm{U} / \mathrm{ml}$ over a similar time period increased activity threefold (or by $300 \%$ ).

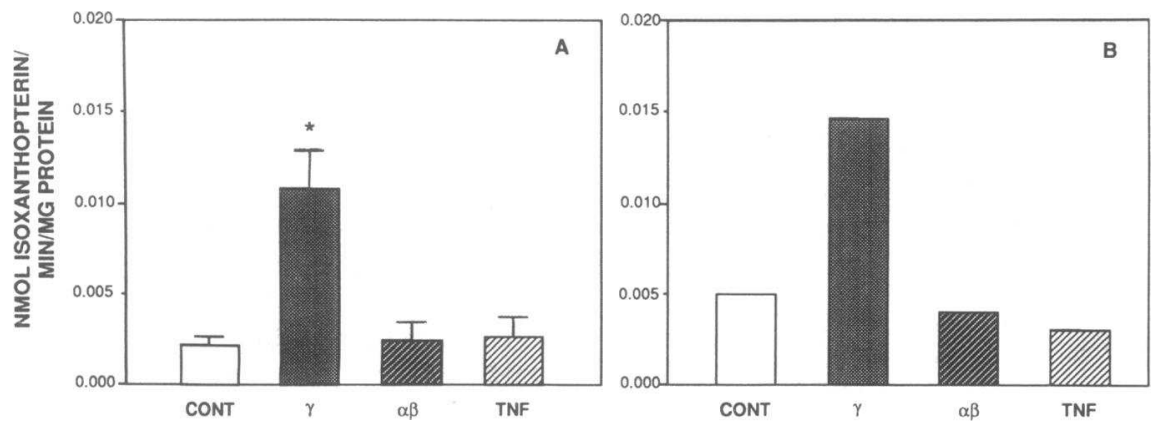

Figure 1. Effect of inflammatory mediators on rat pulmonary endothelial cell $\mathrm{XDH} / \mathrm{XO}$ activity. Cells were exposed for $24 \mathrm{~h}$ to IFN- $\gamma$ $(1,000 \mathrm{U} / \mathrm{ml}), \mathrm{IFN}-\alpha / \beta(1,000 \mathrm{U} / \mathrm{ml})$, or TNF- $\alpha(20 \mathrm{ng} / \mathrm{ml})$. $(A)$ LMVC; $(B)$ PAEC. Data for LMVC represents mean \pm SEM for five experiments; data for PAEC is the mean of two experiments. $* P<0.01$ compared to control. 

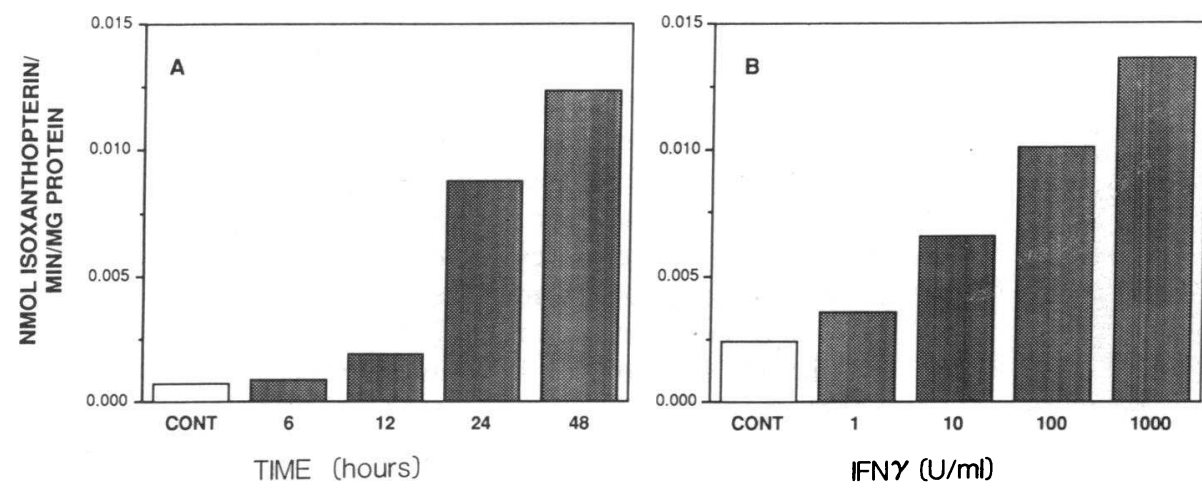

Figure 2. Time course and dose-response effects of IFN- $\gamma$ on rat LMVC XDH/XO activity. $(A) \mathrm{LMVC}$ were exposed to IFN$\gamma(1,000 \mathrm{U} / \mathrm{ml})$ for indicated periods of time; (B) LMVC were exposed to indicated concentrations of IFN- $\gamma$ for $24 \mathrm{~h}$.
New protein synthesis was required for the observed response to IFN- $\gamma$ because it was completely prevented by cycloheximide at a level $(10 \mu \mathrm{g} / \mathrm{ml})$ that had no effect on cell viability (as evidenced by no significant increase in the lactic dehydrogenase activity in culture supernatants). In contrast to the marked stimulatory effect of IFN- $\gamma$ on XDH/XO activity in LMVC, exposure for $24 \mathrm{~h}$ to IFN- $\alpha / \beta(1000 \mathrm{U} / \mathrm{ml})$, TNF- $\alpha$ (20 $\mathrm{ng} / \mathrm{ml})$, IL-1 $(10 \mathrm{ng} / \mathrm{ml})$, IL-6 $(20 \mathrm{ng} / \mathrm{ml})$, LPS $(10 \mu \mathrm{g} / \mathrm{ml})$, or PMA $(50 \mathrm{ng} / \mathrm{ml})$ had no demonstrable effect. With the exception of the interferon preparations that were purified from rat tissues, the activities of the cytokines examined have been demonstrated across species. Thus, of the agents tested, IFN- $\gamma$ appeared to be a selective stimulus for increasing XDH/XO activity in rat LMVC.

IFN- $\gamma$ also increased XDH/XO activity in rat PAEC (Fig. 1 $B$ ). The increase in activity caused by IFN- $\gamma$ in PAEC was similar to that observed in LMVC. As was the case for LMVC, under the conditions employed, only IFN- $\gamma$ increased $\mathrm{XDH} /$ XO activity in PAEC; IFN- $\alpha / \beta$ and TNF- $\alpha$ had no effect on $\mathrm{XDH} / \mathrm{XO}$ activity.

Effect of inflammatory mediators on XDH mRNA transcripts in LMVC. We next performed Northern analysis to test the possibility that the primary mechanism of IFN- $\gamma$ upregulation of XDH/XO activity occurred at the transcriptional level. Control cells exhibited, at all times tested, a low constitutive level of XDH/XO mRNA. Using either of the two cDNA probes generated by PCR, the XDH/XO transcripts were detected as a single $\sim 5.0-\mathrm{kb}$ species. IFN- $\gamma$ markedly increased $\mathrm{XDH} / \mathrm{XO}$ mRNA transcripts in rat LMVC, but had no effect on mRNA for CHO-B, a constitutively expressed gene (Fig. 3). After $24 \mathrm{~h}$ of exposure to $1000 \mathrm{U} / \mathrm{ml} \mathrm{IFN}-\gamma, \mathrm{XDH} / \mathrm{XO} \mathrm{mRNA}$ transcripts increased sevenfold relative to CHO-B transcripts in LMVC. Increased mRNA transcripts in LMVC were observed within $4 \mathrm{~h}$ of exposure to IFN- $\gamma$ and increased with time until reaching a plateau at $48 \mathrm{~h}$ (data not shown).

The IFN- $\gamma$ induction of XDH/XO mRNA could be a consequence of a direct increase in transcriptional rate, the prolongation of XDH/XO mRNA half-life or both. To address the mechanism for the increase, LMVC were treated with IFN- $\gamma$ $(1,000 \mathrm{U} / \mathrm{ml})$, actinomycin $\mathrm{D}(10 \mu \mathrm{g} / \mathrm{ml})$, or both IFN $-\gamma$ and actinomycin D. Actinomycin D inhibited induction of XDH/ XO mRNA caused by IFN- $\gamma$, implying that the process was predominantly dependent on increased transcription of the gene. Nuclear transcription run-on analysis confirmed that IFN- $\gamma$ increased transcription of the $\mathrm{XDH} / \mathrm{XO}$ gene (Fig. 4). In LMVC, the relative transcription rat increased 15 -fold after 24 $\mathrm{h}$ exposure to IFN- $\gamma(1,000 \mathrm{U} / \mathrm{ml})$, while the CHO-B transcription rate remained at the basal level.
We next addressed whether activation of the $\mathrm{XDH} / \mathrm{XO}$ gene by IFN- $\gamma$ was a primary effect or required intermediate protein synthesis (Fig. 5). Treatment of LMVC with cycloheximide alone increased XDH/XO mRNA to a level approximately equal to that seen in the presence of IFN- $\gamma$. When cells were treated with both IFN- $\gamma$ and cycloheximide, there was a synergistic potentiation of XDH/XO mRNA levels. CHO-B mRNA levels showed no change in the presence of cycloheximide.

Effect in vivo of IFN- $\gamma$ on rat lung $X D H / X O$ activity and $m R N A$ transcripts. The physiologic relevance of the in vitro findings was tested by examining the effect of IFN- $\gamma$ on XDH/ $\mathrm{XO}$ activity and mRNA levels in vivo. In rats, $24 \mathrm{~h}$ after intraperitoneal administration of $600,000 \mathrm{U} / \mathrm{kg}$ IFN- $\gamma$, lung XDH/ $\mathrm{XO}$ activity doubled and mRNA levels increased threefold (Fig. 6). CHO-B mRNA levels did not change. Intraperitoneal

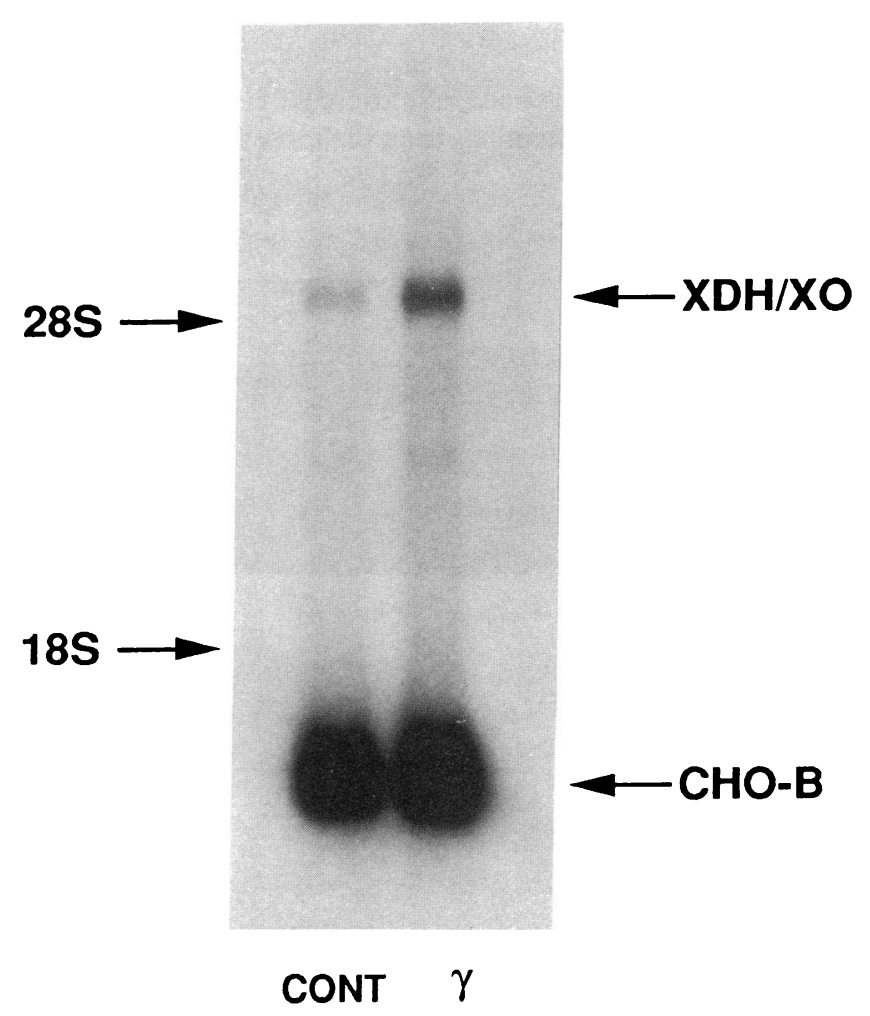

Figure 3. Effect of IFN- $\gamma$ on rat LMVC XDH/XO mRNA level. LMVC were exposed for $24 \mathrm{~h}$ to IFN- $\gamma(1,000 \mathrm{U} / \mathrm{ml})$. Depicted is Northern analysis of mRNA hybridized to XDH/XO cDNA or CHO-B cDNA. (lane 1) control cells; (lane 2) IFN- $\gamma$-treated cells. 


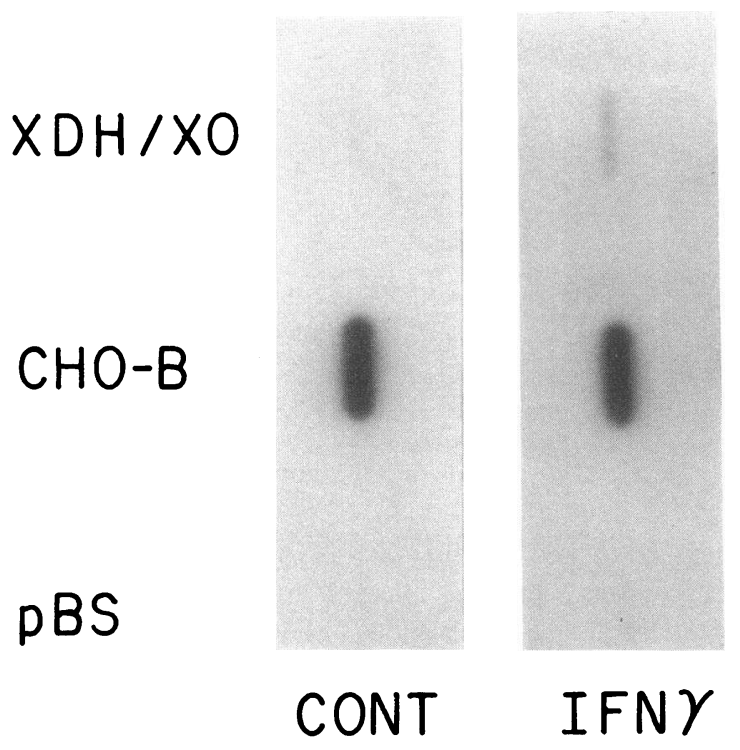

Figure 4. Effect of IFN- $\gamma$ on the relative transcription rate of the $\mathrm{XDH} / \mathrm{XO}$ gene in rat LMVC. Shown is nuclear run-on analysis from control cells or after $24 \mathrm{~h}$ of exposure to IFN- $\gamma(1,000 \mathrm{U} / \mathrm{ml})$. RNA transcripts were labeled by incubation of nuclei with $\left[\alpha^{-32} \mathrm{P}\right] \mathrm{UTP}$. RNA was purified and equal numbers of counts were hybridized onto identical filters onto which $10 \mu \mathrm{g}$ of denatured plasmid DNA had been slotted. pBS is Bluescript plasmid vector used as a control.

injection of the diluent, $\mathrm{PBS}$, had no effect on $\mathrm{XDH} / \mathrm{XO}$ activity or mRNA.

\section{Discussion}

Of the several possible intracellular sources of toxic $\mathrm{O}_{2}$ metabolites, the $\mathrm{XDH} / \mathrm{XO}$ system has been the most thoroughly stud- ied. A large body of evidence suggests that reactive $\mathrm{O}_{2}$ species derived from XO are involved in endothelial and parenchymal injury particularly during reperfusion of ischemic tissue $(1,2)$. However, little is known about mechanisms that govern the regulation of XO or its precursor XDH. In addition, the effect of altering XO activity on relevant pathophysiologic conditions has not been investigated. The present study evaluated the modulation by inflammatory mediators of $\mathrm{XDH} / \mathrm{XO}$ activity and gene expression in rat LMVC and PAEC. We focused primarily on cytokines that cause endothelial cell activation, a process frequently involving gene activation (20). Unstimulated cells constitutively expressed low levels of XDH/XO activity. Of the agents tested, IFN- $\gamma$ selectively increased $\mathrm{XDH} /$ $\mathrm{XO}$ activity. The increase in $\mathrm{XDH} / \mathrm{XO}$ activity was abolished by cycloheximide suggesting that IFN- $\gamma$ induced synthesis of the enzyme. By Northern analysis, the 5.0-kb XDH/XO mRNA was detectable in control cells, but was markedly increased by exposure of the cells to IFN- $\gamma$. Induction of XDH/ XO mRNA was abolished by actinomycin D, also indicating that the increase in enzyme activity is at least partially dependent on increased transcription. Nuclear run-on analysis confirmed increased XDH/XO gene transcription in LMVC in response to IFN- $\gamma$. To our knowledge, these findings are the first demonstrating transcriptional activation of the $\mathrm{XDH} / \mathrm{XO}$ gene.

The ability of interferons to regulate gene expression is the subject of intense study. IFN- $\gamma$, although originally named as such because of its ability to interfere with viral growth, is now known to be a potent intensifier of immune and inflammatory responses. There is significant variability in the action of IFN- $\gamma$ on the expression of various genes. The speed of response varies from extremely rapid (induced by 5 min [21]) to extremely slow (induced by $8 \mathrm{~h}$ [22]), and the response may be transient (22) or sustained for several days (23). The effect of IFN- $\gamma$ on gene expression may or may not require intermediate protein

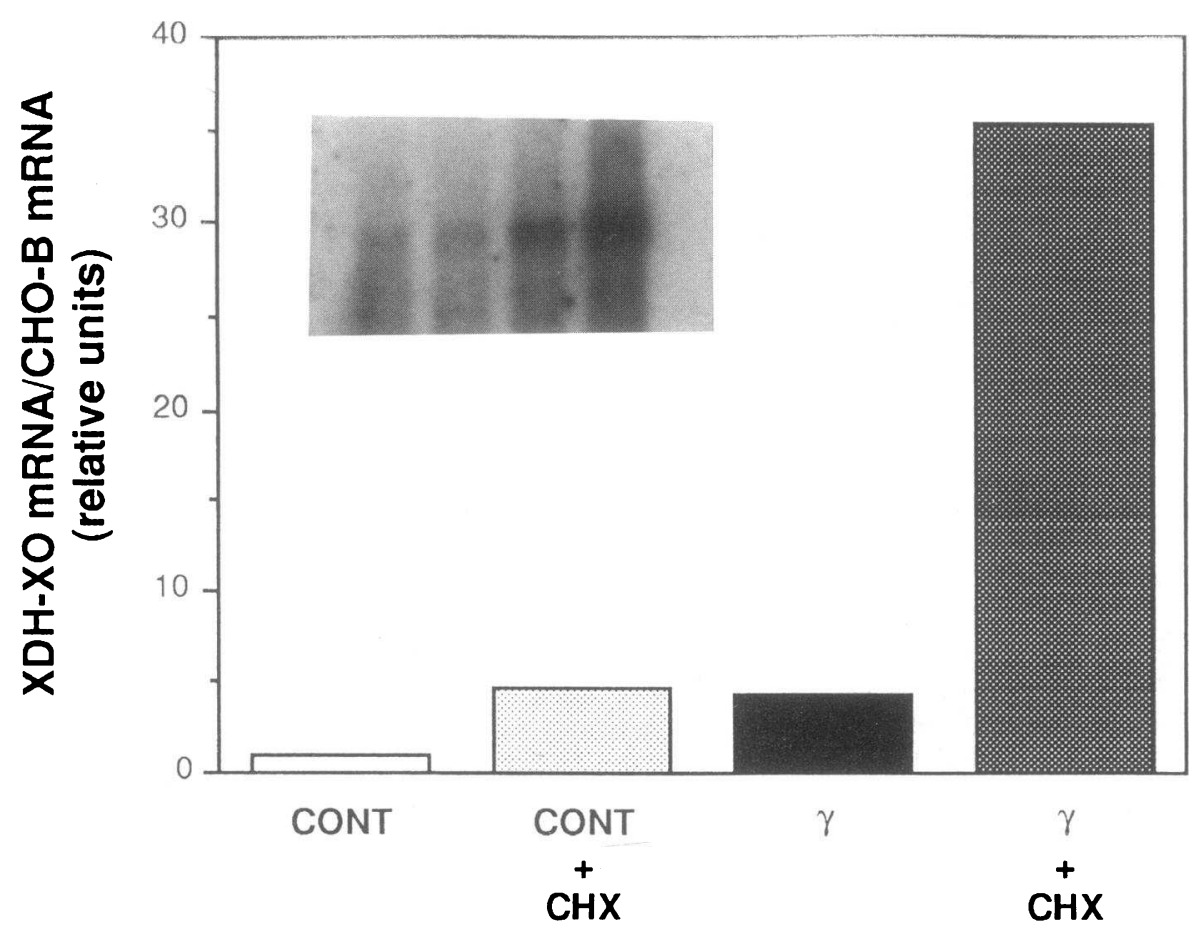

Figure 5. Effect of cycloheximide on rat LMVC XDH/XO mRNA level. LMVC were exposed to $10 \mu \mathrm{g} / \mathrm{ml}$ cycloheximide for $24 \mathrm{~h}$ in the presence or absence of IFN$\gamma(1,000 \mathrm{U} / \mathrm{ml})$. The histogram represents the results of Northern analysis of mRNA hybridized to XDH/XO cDNA and CHO$B$ cDNA. The insert is the Northern analysis hybridized to XDH/XO cDNA. Lanes correspond to respective bars of the histogram. 


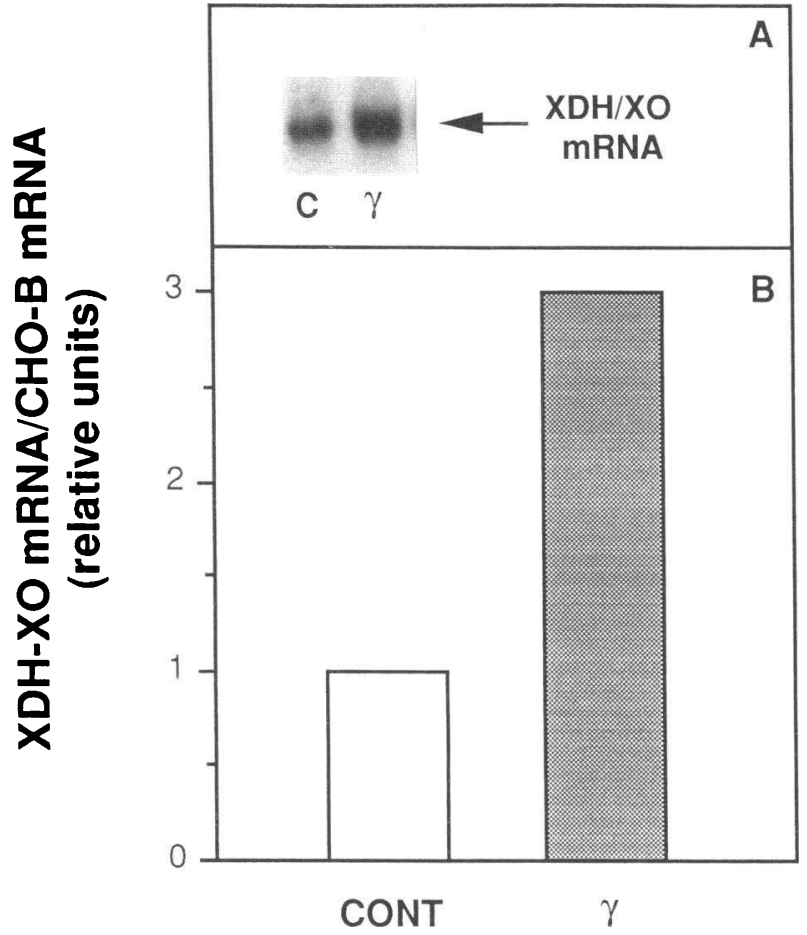

Figure 6. Effect of IFN- $\gamma$ on rat lung XDH/XO mRNA level. $(A)$ Northern analysis of rat lung mRNA hybridized to XDH/XO cDNA. (Lane 1) control rat; (lane 2) IFN- $\gamma$-treated rat $(600,000 \mathrm{U} / \mathrm{kg} ; 24 \mathrm{~h}$ after injection). (B) Histogram from Northern analysis of XDH/XO mRNA/CHO-B mRNA.

synthesis. Therefore, it appears that there are several different mechanisms by which IFN- $\gamma$ may alter gene expression in a particular cell type. In the present study, the induction of $\mathrm{XDH} / \mathrm{XO}$ mRNA by IFN- $\gamma$ was first detectable at $4 \mathrm{~h}$ and was sustained up to $48 \mathrm{~h}$. Induction of the XDH/XO gene by IFN- $\gamma$ did not require new protein synthesis. Instead, cycloheximide alone increased XDH/XO mRNA levels; combining IFN- $\gamma$ plus cycloheximide produced a synergistic increase in the mRNA level. Analogous to our results, in thioglycollate-elicited mouse peritoneal macrophages superinduction with cycloheximide has been described for the IFN- $\gamma$-induced genes TNF- $\alpha$, IL-1, and urokinase (24). We speculate that these findings suggest the presence of a constitutively produced shortlived repressor protein and/or a labile protein with RNase activity, a scenario that has been invoked to explain the superinduction of other genes $(25,26)$. Studies of the effect of cycloheximide on IFN- $\gamma$-induced $\mathrm{XDH} / \mathrm{XO}$ transcriptional rate and mRNA half-life will be needed to fully delineate the mechanism for the observed superinduction.

This is not the first suggestion that $\mathrm{XDH} / \mathrm{XO}$ activity may be modulated by inflammatory mediators. Rat PAEC incubated with purified human recombinant $\mathrm{C}_{5 \mathrm{a}}$ reveal a pronounced conversion of XDH to XO (27). Similar effects were also obtained with TNF- $\alpha$ and the chemotactic peptide FMLP (27). In these studies, the nature of the process resulting in conversion of XDH to XO was not determined nor was the effect of the agents on XDH/XO synthesis or mRNA levels examined. Particularly germane to the current investigation, Ghezzi et al. have reported that various IFN inducers, as well as two different IFN preparations increased XO activity in mouse liver and other tissues $(28,29)$. Again the molecular basis for this increased activity was not determined, but the $24 \mathrm{~h}$ required for peak induction coincides with the time course of transcriptional activation of the XDH/XO gene following IFN$\gamma$ administration observed in the present study. Collectively, these studies support the concept of enhanced XO activity at inflammatory sites and create the imperative to investigate the pathophysiologic consequences of these alterations.

Although the current studies were stimulated by the hypothesis that inflammatory mediators may modulate the susceptibility of ischemic tissue to reperfusion injury, we believe that the insights gained may also be relevant to many clinical conditions in which XO contributes to the pathophysiology. In addition, our findings may help explain some of the biological effects of IFN- $\gamma$. IFN- $\gamma$, for example, is capable of inhibiting cellular proliferation in cell culture and has a role in vivo as a major immune regulator, including antitumor activity. The antiproliferative action of IFN- $\gamma$ has been attributed to down regulation of c-myc in some systems (30) and depletion of tryptophan in other systems (31). Recently, Aune et al. (32) demonstrated that IFN- $\gamma$ inhibited tumor cell growth by enhancing tumor cell production of reactive $\mathrm{O}_{2}$ species, leading to DNA strand breaks, activation of adenosine diphosphate-ribosyl transferase and resultant depletion of NAD. The biochemical mechanism responsible for the enhanced generation of reactive $\mathrm{O}_{2}$ species was not delineated. Based on the results of the current investigation, however, the increased generation of reactive $\mathrm{O}_{2}$ species by the IFN- $\gamma$-stimulated tumor cells may be due to induction of $\mathrm{XO}$.

Induction of $\mathrm{XDH} / \mathrm{XO}$ by IFN- $\gamma$ may also play a role in the tissue injury that occurs in viral infections. Several investigators have reported that host immunological response and XO-mediated events contribute to the morbidity and mortality in virus-infected mice $(8,33-36)$. In these articles, treatment with antilymphocyte sera (35) or cyclophosphamide (32) prolonged survival in virus-infected mice. As early as 1947, Bauer et al. (36) found that XO was increased in mice with yellow fever encephalitis, lymphocytic choriomeningitis and lymphogranuloma inguinale. Other viral illnesses in mice and humans are associated with increased $\mathrm{XDH} / \mathrm{XO}$ activity. For example, $\mathrm{XDH} / \mathrm{XO}$ activity is elevated up to $50 \times$ normal in the serum of patients with infectious hepatitis (37). The recent studies of Akaike et al. (8) provide evidence supporting a central pathologic role for $\mathrm{XDH} / \mathrm{XO}$ in viral disorders. Their results indicate in mice that XO-catalyzed generation of reactive $\mathrm{O}_{2}$ species plays a crucial role in mortality from influenza virus infection.

In conclusion, the present work suggests that IFN- $\gamma$ selectively induces $\mathrm{XDH} / \mathrm{XO}$ activity in rat lung cells by transcriptional activation of its gene. Speculatively we suggest that XOmediated generation of reactive $\mathrm{O}_{2}$ species may contribute to many of the immunopathologic consequences of this lymphokine.

\section{Acknowledgments}

We gratefully acknowledge the help of Mrs. Tammy Boatz in preparation of this manuscript.

This work was supported by HL-40665, HL-02297, HL-02370, HL-21568, HL-44204, from the National Institutes of Health, by the Veterans Administration Research Service, and by the American Lung Association. Bruce C. Marshall is recipient of a Clinical Investigator Award from the NIH and John R. Michael is recipient of a Research Career Development Award from the NIH. 


\section{References}

1. Granger, D. N. 1988. Role of xanthine oxidase and granulocytes in ischemia-reperfusion injury. Am. J. Physiol. 255:H1269-H1275.

2. McCord, J. M. 1985. Oxygen-derived free radicals in postischemic tissue injury. N. Engl. J. Med. 312:158-163.

3. Boda, D., I. Nemeth, P. Hencz and K. Denes. 1984. Effect of allopurinol treatment in premature infants with idiopathic respiratory distress syndrome. Dev. Pharmacol. Ther. 7:357-367.

4. Grum, C. M., R. A. Ragsdale, L. H. Ketai, and R. H. Simon. 1987. Plasma xanthine oxidase activity in patients with adult respiratory distress syndrome. $J$. Crit. Care. 2:22-26.

5. Saez, J. C., P. H. Ward, B. Gunther, and E. Vivaldi. 1984. Superoxide radical involvement in the pathogenesis of burn shock. Circ. Shock. 12:229-239.

6. Athar, M., C. A. Elmets, D. R. Bickers, and H. Mukhtar. 1989. A novel mechanism for the generation of superoxide anions in hematoporphyrin derivative-mediated cutaneous photosensitization. Activation of the xanthine oxidase pathway. J. Clin. Invest. 83:1137-1143.

7. Rodell, T. C., J. C. Cheronis, C. L. Ohnemus, D. J. Piermatlei, and J. E. Repine. 1987. Xanthine oxidase mediates elastase-induced injury to isolated lungs and endothelium. J. Appl. Physiol. 63:2159-2163.

8. Akaike, T., M. Ando, T. Oda, T. Doi, S. Ijiri, S. Araki, and H. Maeda. 1990 Dependence on $\mathrm{O}_{2}^{-}$generation by xanthine oxidase of pathogenesis of influenza virus infection in mice. J. Clin. Invest. 85:739-745.

9. Ryan, U. S., and L. White. 1986. Microvascular endothelium isolation with microcarriers: arterial, venous. J. Tissue Cult. Methods. 10:9-13.

10. Ryan, U. S. 1986. Immunoflourescence and immunocytochemistry of endothelial surface antigens. J. Tissue Cult. Methods. 10:27-30.

11. Stein, O., and Y.Stein. 1980. Bovine aortic endothelial cells display macrophage-like properties towards acetylated $\left[\mathrm{I}^{125}\right]$-labeled low density lipoprotein. Biochim. Biophys. Acta. 620:631-635.

12. Beckman, J. S., D. A. Parks, J. D. Pearson, P. A. Marshall, and B. A. Freeman. 1989. A sensitive assay for measuring xanthine dehydrogenase and oxidase in tissues. Free Radical Biol. Med. 6:607-615.

13. Amaya, Y., K. Yamazaki, M. Sato, K. Noda, T. Nishino, and T. Nishino. 1990. Proteolytic conversion of xanthine dehydrogenase from the NAD-dependent type to the $\mathrm{O}_{2}^{-}$dependent type. J. Biol. Chem. 265:14170-14175.

14. Sanger, F., S. Nicklen, and A. R. Coulson. 1977. DNA sequencing and chain-terminating inhibitors. Proc. Nat. Acad. Sci. USA. 74:5463-5467.

15. Chomczynski, P., and N. Sacchi. 1987. Single-step method for RNA isolation by acid guanidinium thiocyanate-phenol-chloroform extraction. Anal. Biochem. 162:156-159.

16. Harpold, M. M., R. M. Evans, M. Salditt-Georgrieff, and J. E. Darnell. 1979. Production of mRNA in Chinese hamster ovary cells: relationship of the rate of synthesis to the cytoplasmic concentration of nine specific mRNA sequences. Cell. 17:1023-1035.

17. Greenberg, M. E., and E. B. Ziff. 1984. Stimulation of 3 T3 cells induces transcription of the C-fos proto-oncogene. Nature (Lond.). 311:433-438.

18. Groudine, M. M. Peretz, and H. Weintraub. 1981. Transcriptional regulation of hemoglobin switching in chicken embryos. Mol. Cell. Biol. 1:281-288.

19. Dixon, F. J., and F. J. Massey Jr. 1983. Introduction to Statistical Methods. McGraw-Hill, Inc., New York.
20. Pober, J. S., and R. S. Cotran. 1990. The role of endothelial cells in inflammation. Transplantation (Baltimore). 50:537-544.

21. Fan, X. D., G. R. Stark, and B. R. Bloom. 1989. Molecular cloning of a gene selectively induced by gamma interferon from human macrophage cell line U937. Mol. Cell. Biol. 9:1922-1928.

22. Blanar, M. A., E. C. Boettger, and R. A. Flavell. 1988. Transcriptional activation of HLA-DR $\alpha$ by interferon $\gamma$ requires a trans-acting protein. Proc. Nat. Acad. Sci. USA. 85:4672-4676.

23. Caplen, H. S., and S. L. Gupta. 1988. Differential regulation of a cellular gene by human interferon- $\alpha$ and interferon- $\gamma$. J. Biol. Chem. 263:332-339.

24. Collart, M. A., D. Belin, J.-D. Vassalli, S. de Kossodo, and P. Vassalli. 1986. $\gamma$ Interferon enhances macrophage transcription of the tumor necrosis factor/cachectin, interleukin-1, and urokinase genes, which are controlled by short-lived repressors. J. Exp. Med. 164:2113-2118.

25. Linial, M., N. Gunderson, and M. Groudine. 1985. Enhanced transcription of c-myc in bursal lymphoma cells requires continuous protein synthesis. Science (Wash. DC). 230:1126-1132.

26. Visner, G. A., W. C. Dougall, J. M. Wilson, I. A. Burr, and H. S. Nick. 1990. Regulation of manganese superoxide dismutase by lipopolysaccharide, interleukin-1, and tumor necrosis factor. J. Biol. Chem. 265:2856-2864.

27. Friedl, H. P., G. O. Till, U. S. Ryan, and P. A. Ward. 1989. Mediator-induced activation of xanthine oxidase in endothelial cells. FASEB (Fed. Am. Soc. Exp. Biol.) J. 3:2512-2518.

28. Ghezzi, P., M. Bianchi, A. Mantovani, F. Spreafico, and M. Salmona. 1984. Enhanced xanthine oxidase activity in mice treated with interferon and interferon inducers. Biochem. Biophys. Res. Commun. 119:144-149.

29. Ghezzi, P., B. Saccardo, and M. Bianchi. 1986. Induction of xanthine oxidase and heme oxygenase and depression of liver drug metabolism by interferon: a study with different recombinant interferons. J. Interferon Res. 6:251256.

30. Yarden, A., and A. Kimchi. 1986. Tumor necrosis factor reduces c-myc expression and cooperates with interferon- $\gamma$ in Hela cells. Science (Wash. DC). 234:1419-1421.

31. de La Maza, L. M., and E. M. Peterson. 1988. Dependence of the in vitro antiproliferative activity of recombinant human $\gamma$-interferon on the concentration of tryptophan in culture media. Cancer Res. 48:346-350.

32. Aune, T. M., and S. L. Pogue. 1989. Inhibition of tumor cell growth by interferon- $\gamma$ is mediated by two distinct mechanisms dependent upon oxygen tension: induction of tryptophan degradation and depletion of intracellular nicotinamide adenine dinucleotide. J. Clin. Invest. 84:863-875.

33. Hurd, J., and R. B. Heath. 1975. Effect of cyclophosphamide on infections in mice caused by virulent and avirulent strains of influenza virus. Infect. Immun. 11:886-889.

34. Shimomura, E., F. Suzuki, and N. Ishida. 1982. Characterization of cells infiltrating the lungs of $\mathrm{X}$-irradiated and nude mice after influenza virus infection. Microbiol. Immunol. 26:129-138.

35. Suzuki, F., J. Ohya, and N. Ishida. 1974. Effect of antilymphocyte serum on influenza virus infection in mice. Proc. Soc. Exp. Biol. Med. 146:78-84.

36. Bauer, D. J. 1947. Xanthine oxidase and virus growth. Nature (Lond.). 159:438-439.

37. Giler, S. H., O. Sperling, S. Brosh, I. Urca, and A. DeVries. 1975. Serum xanthine oxidase in jaundice. Clin. Chim. Acta. 63:37-40. 